\title{
Diagnostic Value of Fine-Needle Aspiration Biopsy in Major Salivary Gland Masses
}

\author{
Majör Tükrük Bezi Kitlelerinde İnce İğne Aspirasyon Biyopsisinin Tanısal \\ Değeri
}

\author{
Filiz Gülüstan, (1) Mehmet Akif Abakay, (1) Ercan Atasoy, (D) Zahide Mine Yazıcı, (1) İbrahim Sayın \\ University of Health Sciences Turkey, Bakırköy Dr. Sadi Konuk Training and Research Hospital, Clinic of Otorhinolaryngology Head and Neck \\ Surgery, Istanbul, Turkey
}

\begin{abstract}
Objective: To investigate the diagnostic efficacy and accuracy of fine-needle aspiration biopsy (FNAB) in solid and cystic tumors of the major salivary glands, examine the histopathologic distribution and malignancy rates of non-diagnostic cases, and investigate any significant difference between benign and malignant salivary gland tumors according to age and tumor size

Methods: Age, sex, tumor location, side, tumor size, preoperative diagnosis of FNAB, and final histopathological diagnosis of 182 patients with major salivary gland mass were retrospectively evaluated. Each lesion is categorized as solid and cystic. Sensitivity, specificity, positive predictive value (PPV), negative predictive value (NPV), and FNAB accuracy were separately calculated for parotid gland tumors, submandibular gland tumors, solid, and cystic tumors.
\end{abstract}

Results: Among the 182 performed FNABs, 153 were benign, 9 were malignant, and 20 were non-diagnostic. Malignancy was detected in $12.2 \%$ of the parotid gland, $25.9 \%$ of the submandibular gland, and $14.2 \%$ overall. Unlike the parotid gland, when the FNAB of the submandibular gland was non-diagnostic, the final histopathology was most likely to be malignant than benign. No difference was found in the risk of malignancy between the solid and cystic tumors ( $p=0.192)$. The sensitivity, specificity, PPV, NPV, and accuracy of the major salivary gland FNAB in this study were $42.1 \%, 99.3 \%, 88.8 \%, 92.8 \%$, and $92.5 \%$, respectively.

Conclusion: In the context of a non-diagnostic FNAB, high suspicion especially for the submandibular gland tumors is warranted for otorhinolaryngologists. Based on low sensitivity values, FNAB of the major salivary glands is limited as the only diagnostic tool.

Keywords: Fine-needle aspiration biopsy, malignancy, salivary gland, sensitivity, specificity

\section{öz}

Amaç: Majör tükrük bezlerinin solid ve kistik tümörlerinde ince iğne aspirasyon biyopsisinin (iiAB) tanısal etkinliğinin ve doğruluğunun araştııılması, non-diagnostik olguların histopatolojik dağılımının ve malignite oranlarının incelenmesi, yaş ve tümör boyutuna göre benign ve malign tükrük bezi tümörleri arasındaki farkın araştırılması amaçlanmışıı.

Gereç ve Yöntem: Majör tükrük bezi kitlesi olan 182 hastanın yaşı, cinsiyeti, kitle lokalizasyonu, tarafı, kitlenin boyutu, preoperatif iiAB tanısı ve son histopatolojik tanısı retrospektif olarak değerlendirildi. Her bir lezyon solid ve kistik olarak kategorize edildi. Parotis bezi tümörleri, submandibuler bez tümörleri, solid ve kistik tümörler için duyarlılık, özgüllük, pozitif predediktif değeri (PPV), negatif prediktif değeri (NPV) ve doğruluğu ayrı ayrı hesaplandı.

Bulgular: Gerçekleştirilen 182 iïAB'den 153'ü benign, 9'u malign ve 20'si non-diagnostik idi. Parotis bezi kitlelerinin \%12,2'si, submandibuler bez kitlelerinin \%25,9'u ve tüm majör tükrük bezi kitlelerinin ise \%14,2'si maligndi. Parotis bezinden farklı olarak, submandibuler bezin iliAB'si non-diagnostik olduğunda, histopatolojik tanı büyük oranda (\%80) maligndi. Solid ve kistik tümörler arasında malignite riski açısından fark yoktu $(p=0,192)$. Bu çalışmada majör tükrük bezi iliAB'nin duyarlılığı, özgüllüğü, PPV, NPV ve doğruluğu sırasıyla \%42,1, 99,3, 88,8, 92,8 ve \%92,5 olarak bulundu.

Sonuç: Özellikle submandibuler bez tümörleri için non-diagnostik bir lïAB varlığı, yüksek malignite şüphesi açısından kulak burun boğaz uzmanları için uyarıcı olabilir. Majör tükrük bezi tümörlerinde IiAB'nin düşük duyarlılık değerleri nedeniyle tek başına bir tanı aracı olarak kullanımı sınırlıdır.

Anahtar Kelimeler: İnce iğne aspirasyon biyopsisi, malignite, tükrük bezi, duyarlılık, özgüllük

Address for Correspondence: Filiz Gülüstan, University of Health Sciences Turkey, Bakırköy Dr. Sadi Konuk Training and

Research Hospital, Clinic of Otorhinolaryngology Head and Neck Surgery, Istanbul, Turkey

Phone: +90 2124147171 E-mail: filizyirci@hotmail.com ORCID ID: orcid.org/0000-0003-4857-214X

Cite as: Gülüstan F, Abakay MA, Atasoy E, Yazıcı ZM, Sayın I. Diagnostic Value of Fine-Needle Aspiration Biopsy in Major Salivary Gland Masses. Med J Bakirkoy 2021;17:184-189

Received: 21.12 .2020

Accepted: 19.08 .2021 


\section{INTRODUCTION}

Major salivary gland tumors account for $3-10 \%$ of the head and neck cancers and represent a various and heterogeneous group of neoplasms with complex clinicopathologic characteristics and different biological behavior. Their diversity makes the diagnosis challenging $(1,2)$. Treatment of choice for salivary gland tumors is based on clinical evaluation and diagnostic tests: ultrasonography, fineneedle aspiration biopsy (FNAB), endoscopic ultrasoundguided fine-needle aspiration, biopsy, computed tomography, and magnetic resonance imaging (3). FNAB is a safe and reliable tool for salivary gland lesion diagnosis. It is simple, relatively painless, and easily repeated if another sample is needed. However, its diagnostic accuracy is still controversial despite being used for many years (4).

Several non-neoplastic lesions, benign neoplasms, and malignancies of the salivary gland present with a predominant or minor cystic component (5). Distinguishing these lesions from one another is important since patient management often differs among these groups. FNAB is often used to guide management decisions; however, it is frequently nondiagnostic in assessing cysts, as the aspirate may only capture cystic fluid. Despite non-diagnostic FNAB results, at least one-third of cystic salivary gland lesions are neoplastic $(6,7)$.

This study aimed to investigate the diagnostic efficacy and accuracy of FNAB in solid and cystic tumors of the major salivary glands, examine the histopathologic distribution and malignancy rates of non-diagnostic cases, and investigate any significant difference between benign and malignant salivary gland tumors according to age and tumor size.

\section{METHODS}

Between February 2010 and February 2020, 267 cases that undergone parotidectomy or submandibular gland resection due to major salivary gland tumors in the otorhinolaryngology department of our tertiary referral center were retrospectively examined. Patients who underwent open biopsy before surgery, patients with unavailable $F N A B$, patients with non-diagnostic cytology depend on insufficient cellularity, and patients with preoperative FNAB done at an outside hospital, except in the situation where the original slides were transferred to our center for review by our institution pathologists, were excluded. Age, sex, tumor location, side, tumor size as measured by ultrasound/ computed tomography/magnetic resonance imaging (by measuring the largest diameter of tumor), preoperative FNAB diagnosis, and final histopathological diagnosis were noted. Major salivary gland lesions were categorized as solid and cystic (pure cystic or has a cystic component in radiologic imaging studies) based on radiology reports and from available ultrasound, computed tomography, and/or magnetic resonance imaging studies. In addition, patients without any imaging studies or those with insufficient imaging report details were excluded. The study protocol was approved by the Institutional Ethics Committee of University of Health Sciences Turkey, Bakırköy Dr. Sadi Konuk Training and Research Hospital (date: 17.02.2020, no: 2020/77). The study was conducted by the principles of the Helsinki declaration.

All of the FNAB was performed under ultrasound guidance using a 25 gauge needle and standard aspiration technique without local anesthesia in the radiology department of our hospital. The needle is inserted from a single point and moved in 3-4 directions through the tumor. After obtaining enough samples, the needle is withdrawn and detached from the syringe. The aspirate is sprayed on at least 4 glass slides, smeared, fixed in alcohol for hematoxylin-eosin stain, and sent to the pathology laboratory. All specimens were examined in the Pathology Department of our hospital. Preoperative cytological findings of the FNAB were classified as benign, non-diagnostic, and malignant. The subtypes were noted if possible. Final histopathological diagnosis was grouped as benign and malignant, and typing was noted. When the FNAB is non-diagnostic, our usual practice in such cases is to perform a second FNAB, if the cytological diagnosis is still not obtained with the second FNAB, then it is accepted as non-diagnostic.

FNAB results were compared to the final surgical pathology. Sensitivity, specificity, positive predictive value (PPV), negative predictive value (NPV), and FNAB diagnostic accuracy was calculated, and patients with non-diagnostic cytology were excluded from this analysis. Sensitivity, specificity, PPV, NPV, and FNAB accuracy were separately calculated for parotid gland tumors, submandibular gland tumors, solid, and cystic tumors, and also patients with nondiagnostic cytology were excluded from this analysis. The Mann-Whitney $U$ test was used to examine the relationship of age and tumor size with the final histopathological diagnosis. The risk of malignancy between solid and cystic tumors was examined with the chi-square test. The confidence interval was $95 \%$ and $p$-values of $<0.05$ were considered to be significant.

\section{RESULTS}

Of the 267 retrospectively investigated patients, 85 were excluded due to unavailable FNAB results and/or insufficient 
details of imaging reports. A total of 182 patients were retrospectively examined, wherein 95 (52.2\%) were male and 87 (47.8\%) were female, with an average age of $49.07 \pm 16.43$ years (range: 10-82 years). The mean age of patients with benign final histopathology was $48.79 \pm 15.96$ years (range: 10-80 years, median: 52 years), whereas $50.77 \pm 19.23$ years (range: $14-82$ years, median: 56 years) in malignant tumors, without any statistically significant difference $(p=0.7)$. The mean size of the salivary gland tumors with benign final histopathology was $27.41 \pm 14.37 \mathrm{~mm}$ (range: $5-65 \mathrm{~mm}$, median: $25 \mathrm{~mm}$ ), whereas $30.61 \pm 16.33 \mathrm{~mm}$ (range: $16-120$ $\mathrm{mm}$, median: $27 \mathrm{~mm}$ ) in malignant ones. No statistically significant difference was found between the benign and malignant tumors $(p=0.348)$.

Samples were obtained from the parotid in 155 (85.2\%, 76 right parotids, 79 left parotids) cases and submandibular in 27 (14.8\%, 13 right submandibular, 14 left submandibular) cases. Among the 182 performed FNABs, 153 (84\%) were benign, 9 (4.9\%) were malignant, and 20 (10.9\%) were nondiagnostic. FNAB distribution and final histopathologic results among the parotid and submandibular gland tumors are shown in Table 1. Malignancy was detected in $12.2 \%(n=19)$ of the parotid gland tumors, $25.9 \%(n=7)$ of the submandibular gland tumors, and $14.2 \% \quad(n=26)$ overall based on final histopathology. The most common benign diagnosis among the parotid gland tumors were pleomorphic adenoma $(n=69,50.7 \%)$ and Warthin's tumor $(n=50,36.7 \%)$, whereas the most common malignant diagnoses were mucoepidermoid carcinoma $(n=5,26.3 \%)$ and acinic cell carcinoma ( $n=4,21 \%$; Table 2). The most common benign diagnosis among the submandibular gland tumors was pleomorphic adenoma $(n=19,95 \%)$ and the most common malignant diagnosis was adenoid cystic

Table 1. Distribution of FNAB results and final histopathologic diagnosis among parotid and submandibular gland tumors

\begin{tabular}{lll}
\hline & \multicolumn{2}{l}{ Final histopathologic diagnosis, } \\
$\mathbf{n}(\%)$ & Malignant \\
\hline FNAB diagnosis & Benign & \\
\hline Parotid gland & $123(93.1)$ & $9(6.8)$ \\
\hline Benign ( $\mathrm{n}=132)$ & $1(12.5)$ & $7(87.5)$ \\
\hline Malignant ( $\mathrm{n}=8)$ & $12(80)$ & $3(20)$ \\
\hline Non-diagnostic $(\mathrm{n}=15)$ & & $2(9.5)$ \\
\hline Submandibular gland & $19(90.4)$ & $1(100)$ \\
\hline Benign ( $\mathrm{n}=21)$ & $0(0)$ & $4(80)$ \\
\hline Malignant $(\mathrm{n}=1)$ & $1(20)$ & \\
\hline Non-diagnostic $(\mathrm{n}=5)$ & &
\end{tabular}

FNAB: Fine-needle aspiration biopsy carcinoma ( $n=2,28.5 \%$; Table 3). When the FNAB of the parotid gland is non-diagnostic, the final histopathology was most likely to be benign (80\%) than malignant (20\%). In contrast, when the FNAB of the submandibular gland was non-diagnostic, the final histopathology was most likely to be malignant (80\%) than benign (20\%). The distribution of final histopathology in non-diagnostic FNAB cases was presented in Table 4. A total of 125 solid (68.6\%) and 57 cystic tumors (31.3\%) (19 pure cystic, 38 have cystic component) were found among the major salivary gland tumor cases. FNAB of solid tumors accounting for 14 (11.2\%) were nondiagnostic, whereas 6 (10.5\%) FNAB of cystic tumors were non-diagnostic (Table 5). Malignancy was detected in 12\% $(n=15)$ of solid tumors and $19.2 \%(n=11)$ in cystic tumors based on final histopathology. A higher malignancy rate was

Table 2. Final histopathologic diagnosis of parotid gland lesions

\begin{tabular}{|c|c|c|}
\hline & $\mathbf{n}$ & $\%$ \\
\hline \multicolumn{3}{|l|}{ Benign $(n=136)$} \\
\hline Pleomorphic adenoma & 69 & 50.7 \\
\hline Warthin tumor & 50 & 36.7 \\
\hline Granulomatous sialadenitis & 2 & 1.4 \\
\hline Lymphoepithelial sialadenitis & 2 & 1.4 \\
\hline Lymphoepithelial cyst & 2 & 1.4 \\
\hline Lipoma & 2 & 1.4 \\
\hline Oncocytoma & 2 & 1.4 \\
\hline Basal cell adenoma & 1 & 0.7 \\
\hline Castleman disease & 1 & 0.7 \\
\hline Epidermoid cyst & 1 & 0.7 \\
\hline İnt alymphoid epidermoid cyst & 1 & 0.7 \\
\hline Cavernous hemangioma & 1 & 0.7 \\
\hline Non-specific chronic sialadenitis & 1 & 0.7 \\
\hline Parotid duct cyst & 1 & 0.7 \\
\hline \multicolumn{3}{|l|}{ Malignant $(n=19)$} \\
\hline Mucoepidermoid carcinoma & 5 & 26.3 \\
\hline Acinic cell carcinoma & 4 & 21 \\
\hline Ductal carcinoma & 2 & 10.5 \\
\hline Myoepithelial carcinoma & 2 & 10.5 \\
\hline Squamous cell carcinoma & 2 & 10.5 \\
\hline Adenoid cystic carcinoma & 1 & 5.2 \\
\hline B-cell non-hodgkin lymphoma & 1 & 5.2 \\
\hline Carcinoma ex-pleomorphic adenoma & 1 & 5.2 \\
\hline Cystadenocarcinoma & 1 & 5.2 \\
\hline
\end{tabular}


Table 3. Final histopathologic diagnosis of submandibular gland lesions

\begin{tabular}{lll}
\hline & $\mathrm{n}$ & $\%$ \\
\hline Benign ( $\mathbf{n}=\mathbf{2 0})$ & & \\
\hline Pleomorphic adenoma & 19 & 95 \\
\hline Non-specific chronic sialadenitis & 1 & 5 \\
\hline Malign ( $\mathbf{n}=\mathbf{7}$ ) & & \\
\hline Adenoid cystic carcinoma & 2 & 28.5 \\
\hline Hodgkin lymphoma & 1 & 14.2 \\
\hline Myoepithelial carcinoma & 1 & 14.2 \\
\hline Malign epithelial tumor & 1 & 14.2 \\
\hline Solitary fibrous tumor & 1 & 14.2 \\
\hline Low-grade mesenchymal tumor & 1 & 14.2 \\
\hline
\end{tabular}

Table 4. Distribution of final histopathology in non-diagnostic FNAB cases

\begin{tabular}{ll}
\hline Final Histopathology & $\mathrm{n},(\%)$ \\
\hline Parotid gland ( $\mathrm{n}=15)$ & \\
\hline Benign & $3,(20)$ \\
\hline Pleomorphic adenoma & $3,(20)$ \\
\hline Whatin tumor & $2,(13.3)$ \\
\hline Lymphoepithelial cyst & $1,(6.6)$ \\
\hline Epidermoid cyst & $1,(6.6)$ \\
\hline Granulomatous sialadenitis & $1,(6.6)$ \\
\hline Castleman disease & $1,(6.6)$ \\
\hline Cavernous hemangioma & $1,(6.6)$ \\
\hline Malignant & $1,(6.6)$ \\
\hline B-cell non-Hodgkin lymphoma & $1,(6.6)$ \\
\hline Mucoepidermoid carcinoma & $1,(20)$ \\
\hline Myoepithelial carcinoma & $1,(20)$ \\
\hline Submandibular gland ( $\mathrm{n}=5)$ & $1,(20)$ \\
\hline Benign & \\
\hline Pleomorphic adenoma & $1,(20)$ \\
\hline Malignant & \\
\hline Low-grade mesenchymal tumor & \\
\hline Hodgkin lymphoma & \\
\hline Solitary fibrous tumor & \\
\hline FNAB: Fine-needle aspiration biopsy & \\
\hline
\end{tabular}

found in cystic tumors; however, no difference was found in the risk of malignancy between solid and cystic tumors $(p=0.192)$.
Table 5. FNAB of solid and cystic tumors

\begin{tabular}{|c|c|c|c|c|}
\hline \multicolumn{5}{|c|}{ FNAB } \\
\hline & $\begin{array}{l}\text { Benign } \\
n \%\end{array}$ & $\begin{array}{l}\text { Malignant } \\
\mathrm{n} \%\end{array}$ & $\begin{array}{l}\text { Non-diagnostic } \\
\mathrm{n} \%\end{array}$ & $\begin{array}{l}\text { Total } \\
\mathrm{n} \%\end{array}$ \\
\hline $\begin{array}{l}\text { Solid } \\
\text { tumors }\end{array}$ & 105,84 & $6,4.8$ & $14,11.2$ & 125,100 \\
\hline $\begin{array}{l}\text { Cystic } \\
\text { tumors }\end{array}$ & $48,84.2$ & $3,5.2$ & $6,10.5$ & 57,100 \\
\hline Total & 153,84 & $9,4.9$ & $20,10.9$ & 182,100 \\
\hline
\end{tabular}

A total of 142 true-negatives, 8 true-positives, 11 falsenegatives, and 1 false-positive case was found among the major salivary gland tumors, and the sensitivity, specificity, PPV, NPV, and accuracy of the major salivary gland FNAB in this study were $42.1 \%, 99.3 \%, 88.8 \%, 92.8 \%$, and 92.5 $\%$, respectively. The final histopathology of the only falsepositive case was the Warthin's tumor, which was located in the parotid gland. Diagnostic accuracy measures among solid/cystic tumors, parotid/submandibular gland, and overall were shown in Table 6.

\section{DISCUSSION}

Salivary gland tumors are rare, mostly benign, with an annual estimated global incidence is $0.4-13.5$ per 100,000 people. More than $50 \%$ of all primary salivary gland tumors occur in the major salivary glands, which are mainly present in the parotid gland, with $80 \%-85 \%$ being benign. Overall, tumors are more common in the parotid gland; however, the incidence of malignancy is higher in the submandibular and minor salivary glands. Histologically, the most common type of benign salivary gland neoplasms is a pleomorphic adenoma, and the most common malignant salivary gland tumors are mucoepidermoid and adenoid cystic carcinomas (3,8-10). Consistent with the literature, $85.2 \%$ of major salivary gland tumors were located in the parotid gland and $14.8 \%$ in the submandibular gland in our study. Based on final histopathology, $85.1 \%$ of 182 tumors were benign. The most common benign neoplasm is a pleomorphic adenoma and the malignant neoplasm is mucoepidermoid carcinoma.

FNAB is a safe, easy-to-apply, and inexpensive diagnostic procedure that is widely applied since the 1980s in the preoperative diagnosis of the salivary gland masses, while presenting low rates of complication and patient morbidity. However, the value of FNAB in preoperative diagnosis of salivary gland lesions is still being debated (11-13). In our study, $84 \%(n=153)$ of FNABs were benign, $4.9 \%(n=9)$ were malignant, and $10.9 \%(n=20)$ were non-diagnostic. Feinstein et al. (14) reported that when FNAB of the parotid gland was 


\begin{tabular}{|c|c|c|c|c|c|}
\hline & Parotid gland & Submandibular gland & Solid tumors & Cystic tumors & Overal \\
\hline Sensitivity \% & 43.7 & 33.3 & 45.4 & 37.5 & 42.1 \\
\hline Specificity \% & 99.1 & 100 & 99 & 100 & 99.3 \\
\hline PPV \% & 87.5 & 100 & 83.3 & 100 & 88.8 \\
\hline NPV \% & 93.1 & 90.4 & 94.2 & 89.5 & 92.8 \\
\hline Accuracy \% & 92.8 & 90.9 & 95.4 & 90 & 92.5 \\
\hline
\end{tabular}

non-diagnostic, the final pathology was more likely benign than malignant and, when FNAB of the submandibular gland was non-diagnostic the final pathology was equally likely benign versus malignant. Similarly, when the FNAB of the parotid gland is non-diagnostic, the final histopathology was found to be most likely benign than malignant. In contrast with their findings, when the FNAB of the submandibular gland was non-diagnostic, the final histopathology was found to be most likely malignant than benign. Boursiquot et al. (7) stated that FNAB is frequently non-diagnostic in assessing cysts, as the aspirate only captures cystic fluid. In our study, similar non-diagnostic FNAB rates were found in solid (11.2\%) and cystic (10.5\%) tumors. This was related to our exclusion criteria of non-diagnostic cytology cases that depend on insufficient cellularity. In addition, they reported that, in line with our findings, no difference was found in the risk of malignancy between the cystic and solid tumors (7).

In the management of salivary gland tumors, distinguishing malignant tumors from benign ones is very important to determine the therapeutic approach. Olsen et al. (15) stated in their study that FNAB was found with a high false-negative rate, up to $20 \%$, that limits its usefulness and, therefore they reported that they strictly rely on frozen section results for surgical decision making. False-negative rate was relatively small in our study, $(6.7 \%, \mathrm{n}=11)$ accounting for $20(10.9 \%)$ non-diagnostic cases, wherein $35 \%(n=7)$ were malignant based on final histopathology.

The diagnostic value of FNAB in salivary gland tumors was assessed in several studies, and a wide range of results on accuracy for detecting malignancy was reported, with sensitivities ranging from $33 \%$ to $100 \%$ and specificities ranging from $67 \%$ to $100 \%$ (16). In the study by Kechagias et al. (4) they reported that the sensitivity and specificity of FNAB for salivary gland masses were $90 \%$ and $98 \%$, respectively. In the study of Stow et al. (17) they reported that the sensitivity and specificity in their series were $86.9 \%$ and $96.3 \%$, respectively. In our study, despite high specificity values, the sensitivity values for submandibular gland tumors, parotid gland tumors, cystic masses, solid masses, and overall were $33.3 \%, 43.7 \%, 37.5 \%, 45.4 \%$, and $42.1 \%$, respectively. Therefore, despite the relatively high sensitivity values of some other studies in the literature, approximately $58 \%$ of malignant tumors of the major salivary glands were undiagnosed by FNAB in our study $(4,7,12,14,17)$. Based on our findings, benign FNAB cytology should not be trusted and FNAB should not overcome the clinical experience and intraoperative findings. An otorhinolaryngologist should be aware of the other signs of a malignant tumor, such as anamnesis of persistent pain in the area and a rapidly growing tumor of a salivary gland.

The major limitation of this study is its retrospective nature, which included only those patients who proceeded to surgery. FNAB results could not be evaluated in terms of determining the usefulness of FNAB for patients who did not elect surgery or who pursued surgery elsewhere. In addition, the impact of different pathologists on FNAB cytology was not assessed.

\section{CONCLUSION}

Study results revealed that when the FNAB of the submandibular gland was non-diagnostic, unlike the parotid gland, the final histopathology was most likely malignant than benign. In the context of a non-diagnostic FNAB, a high suspicion for salivary gland tumors especially for the submandibular gland tumors may be warranted for otorhinolaryngologists. Similar non-diagnostic FNAB rates in solid and cystic tumors were found. Our findings demonstrated that FNAB of the parotid gland, submandibular gland, cystic, and solid masses has limitations as an only diagnostic tool. FNAB has not had a reliable sensitivity in terms of screening malignancy. For a surgeon to complement FNAB diagnosis with a patient's medical history, physical examination, own clinical experience, and radiological imaging are more appropriate.

\section{ETHICS}

Ethics Committee Approval: The study were approved by the University of Health Sciences Turkey, Bakırköy Dr. Sadi Konuk Training and Research Hospital of Local Ethics Committee (protocol number: 2020/77, date:17.02.2020). 
Informed Consent: Consent form was filled out by all participants.

\section{Authorship Contributions}

Surgical and Medical Practices: F.G., M.A.A., Z.M.Y., I.S., Concept: F.G., M.A.A., E.A., Design: F.G., E.A., Z.M.Y., Data Collection or Processing: F.G., M.A.A., E.A., Analysis or Interpretation: F.G., M.A.A., E.A., Z.M.Y., I.B., Literature Search: F.G., E.A., I.S., Writing: F.G., Z.M.Y., I.S.

Conflict of Interest: No conflict of interest was declared by the authors.

Financial Disclosure: The authors declared that this study received no financial support.

\section{REFERENCES}

1. Carlson ER, Schlieve T. Salivary Gland Malignancies. Oral Maxillofac Surg Clin North Am 2019;31:125-44.

2. Yariv O, Popovtzer A, Wasserzug O, Neiderman NC, Halperin D, Lahav $Y$, et al. Usefulness of ultrasound and fine needle aspiration cytology of major salivary gland lesions. Am J Otolaryngol 2020;41:102293.

3. Israel Y, Rachmiel A, Ziv G, Nagler R. Diagnostic and therapeutic modalities for 287 malignant and benign salivary tumors: A cohort study. J Craniomaxillofac Surg 2017;45:585-8.

4. Kechagias N, Ntomouchtsis A, Valeri R, Patrikidou A, Kitikidou K, Xirou $P$, et al. Fine-needle aspiration cytology of salivary gland tumours: a 10-year retrospective analysis. Oral Maxillofac Surg 2012;16:35-40.

5. Takita H, Takeshita T, Shimono T, Tanaka H, Iguchi H, Hashimoto $\mathrm{S}$, et al. Cystic lesions of the parotid gland: radiologic-pathologic correlation according to the latest World Health Organization 2017 Classification of Head and Neck Tumours. Jpn J Radiol 2017;35:62947.

6. Faquin WC, Rossi ED, Baloch Z, Barkan GA, Foschini M, Kurtycz DFl, et al. Atypia of undetermined significance. In: Faquin WC,
Rossi ED, editors. The Milan system for reporting salivary gland cytopathology. Cham: Springer; 2018. p. 43-54.

7. Boursiquot BC, Fischbein NJ, Sirjani D, Megwalu UC. Risks of Neoplasia and Malignancy in Surgically Resected Cystic Parotid Lesions. Otolaryngol Head Neck Surg 2020;162:79-86.

8. Tian Z, Li L, Wang L, Hu Y, Li J. Salivary gland neoplasms in oral and maxillofacial regions: a 23-year retrospective study of 6982 cases in an eastern Chinese population. Int J Oral Maxillofac Surg 2010;39:235-42.

9. Sood S, McGurk M, Vaz F. Management of Salivary Gland Tumours: United Kingdom National Multidisciplinary Guidelines. J Laryngol Otol 2016;130:S142-9.

10. Comoglu S, Ozturk E, Celik M, Avci H, Sonmez S, Basaran B, et al. Comprehensive analysis of parotid mass: A retrospective study of 369 cases. Auris Nasus Larynx 2018;45:320-7.

11. Ramírez-Pérez F, González-García R, Hernández-Vila C, MonjeGil F, Ruiz-Laza L. Is fine-needle aspiration a reliable tool in the diagnosis of malignant salivary gland tumors? J Craniomaxillofac Surg 2017;45:1074-7.

12. Altin F, Alimoglu Y, Acikalin RM, Yasar H. Is fine needle aspiration biopsy reliable in the diagnosis of parotid tumors? Comparison of preoperative and postoperative results and the factors affecting accuracy. Braz J Otorhinolaryngol 2019;85:275-81.

13. Colella G, Cannavale R, Flamminio F, Foschini MP. Fine-needle aspiration cytology of salivary gland lesions: a systematic review. J Oral Maxillofac Surg 2010;68:2146-53.

14. Feinstein AJ, Alonso J, Yang SE, St John M. Diagnostic Accuracy of Fine-Needle Aspiration for Parotid and Submandibular Gland Lesions. Otolaryngol Head Neck Surg 2016;155:431-6.

15. Olsen KD, Moore EJ, Lewis JE. Frozen section pathology for decision making in parotid surgery. JAMA Otolaryngol Head Neck Surg 2013;139:1275-8.

16. Schmidt RL, Hall BJ, Wilson AR, Layfield LJ. A systematic review and meta-analysis of the diagnostic accuracy of fine-needle aspiration cytology for parotid gland lesions. Am J Clin Pathol 2011;136:4559.

17. Stow N, Veivers D, Poole A. Fine-needle aspiration cytology in the management of salivary gland tumors: an Australian experience. Ear Nose Throat J 2004;83:128-31. 